\title{
CSSR2019
}
6th International Conference on Science \& Social Research 2019
https://cssr.uitm.edu.my/2019/

Parkroyal Penang Resort, Batu Ferringhi, Pulau Pinang, Malaysia, 04-05 Dec 2019

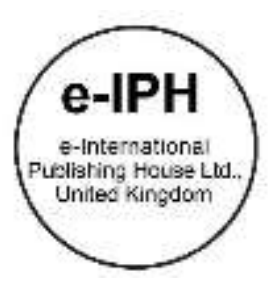

\section{View and Experiences of Unwanted Pregnancy among Malays Teenage Mother}

\author{
Fatimah Sham ${ }^{1,3}$, Afiqah Ismail1, Tuan Nor Ashikin Tuan Him¹, Salmi Razali 2, 3 \\ ${ }^{1}$ Faculty of Health Science, Puncak Alam Campus, Universiti Teknologi MARA 42300 Selangor Malaysia \\ 2 Department of Psychiatry, Faculty of Medicine, Sungai Buloh Campus, Universiti Teknologi MARA, 47000 Selangor Malaysia \\ ${ }^{3}$ Maternofetal and Embryology Research Group, Faculty of Medicine, Sungai Buloh Campus, Universiti Teknologi MARA 47000 \\ Selangor Malaysia
}

fatimah2886@salam.uitm.edu.my, afiqahismail219@gmail.com, ashikinth@yahoo.com.my, drsalmi@gmail.com

Tel of 1st Author: 03-32584520

\begin{abstract}
Ex-nuptial pregnancy among teenagers in Malaysia associates with negative consequences. However, perspective from them is lacking. To explore their experiences and perspective in addressing this phenomenon. In-depth face-to-face interviews were conducted with informed consent among 10 young women who experienced becoming unwed mothers during adolescents. Data were encoded and analyse using Qualitative Data Analysis Miner Program and interpretative phenomenological analysis. Four themes emerged; sexual activity trajectory, motherhood struggles to them, formula of resilience teenage mothers and life after misery. Perspectives from them are vital. Great support strategies could assist them for a better life.
\end{abstract}

Keywords: teenage, motherhood, pregnant, sexuality, Malaysia

eISSN: 2398-42870 2021. The Authors. Published for AMER ABRA CE-Bs by e-International Publishing House, Ltd., UK. This is an open access article under the CC BYNC-ND license (http://creativecommons.org/licenses/by-nc-nd/4.0/). Peer-review under responsibility of AMER (Association of Malaysian Environment-Behaviour Researchers), ABRA (Association of Behavioural Researchers on Asians/Africans/Arabians) and cE-Bs (Centre for Environment-Behaviour Studies), Faculty of Architecture, Planning \& Surveying, Universiti Teknologi MARA, Malaysia.

DOI: https://doi.org/10.21834/ebpj.v6iSI4.2897

\subsection{Introduction}

Early and unintended pregnancy (EUP) is a global concern affecting both high-income countries (HIC) and low and middle-income countries (LMIC). It has a significant impact on adolescents' lives, especially girls, regarding their health, social, economic, and education outcomes (UNESCO, 2017). Adolescent pregnancy is commonly associated with adverse psychosocial, socioeconomic, and health outcomes (Sedgh et al., 2015). Compared with older mothers, women who become pregnant in adolescence tend to have lower levels of educational attainment and socioeconomic status, and children of adolescent mothers are more likely to have low birthweight and developmental and behavioral difficulties (Case et al., 2015; Ganchimeg et al., 2014; Kawakita et al., 2016).

Various factors were contributing to this predicament. Key risk factors for teenage pregnancy include poverty, inadequate parental supervision, low educational expectations, and peer influence. Many of these likely relate to social disadvantage (Azri et al., 2015).

\subsection{Literature Review}

Youth lack sexual knowledge but have a more liberal attitude toward sexuality. They are more likely to clarify their doubts with their peers. Their primary source for gathering information was the internet, which is also considered the most reliable source. Individuals eISSN: 2398-4287@ 2021. The Authors. Published for AMER ABRA cE-Bs by e-International Publishing House, Ltd., UK. This is an open access article under the CC BYNC-ND license (http://creativecommons.org/licenses/by-nc-nd/4.0/). Peer-review under responsibility of AMER (Association of Malaysian Environment-Behaviour Researchers), ABRA (Association of Behavioural Researchers on Asians/Africans/Arabians) and cE-Bs (Centre for Environment-Behaviour Studies), Faculty of Architecture, Planning \& Surveying, Universiti Teknologi MARA, Malaysia.

DOI: https://doi.org/10.21834/ebpj.v6iSI4.2897 
who are likely to indulge in sexual behaviors through media are more likely to indulge in sexual behaviors with themselves and others, indicating the link between the influence of media and sexual behaviors (Behavior et al., 2019).

Study shows that teenage mothers were physically and biologically immature to go through the pregnancy period (Azri et al., 2015). Subsequent consequences and challenges require serious attention and support from the community as insufficient support harms their pregnancy and well-being. The study by Khairani et al. (2010) supported this report that teenage mothers in Malaysia tend to have less antenatal care follow-up, anemia, unsure of the expected delivery date, lower birth weight, and perinatal complications within the delivery.

Saim (2013) reports that local society usually rejected these unwed young pregnant women and young mothers, which causes most of these teens to be housed in shelters either by their family members or voluntarily to cover the shame of this extramarital pregnancy. As a result, this drives them to have postpartum depression as they lost their attachment with their families, especially as they struggle to live a new life in a shelter and at the same time experience new pregnancy, childbirth, and confinement without immediate family. Thus, this study aims to rule out the strategies addressing this phenomenon from the perspective of the previously or currently unwed pregnant girls or young women to continue with their pregnancy.

\subsection{Methodology}

This study is qualitative research investigating the meaning of lived experiences of having unintended teenage pregnancy and understanding the strategies addressing this phenomenon from the previously unwed pregnant girls or young women. In-depth interviews were conducted face-to-face with ten young women aged 18 to 25 who had experienced becoming unwed mothers when they were between 10 to 19 years old. Participants were recruited during their stay at two shelters in Selangor in April 2019.

The participants were chosen purposely for their rich lived experiences of becoming unwed pregnant teenagers. The researcher took the initial approach after participants were interviewed by asking about their daily life routine in this shelter. It is the beginning of a conversation so that participants are more comfortable and encourage a good rapport. Next, the researcher asked questions related to their demographic characteristic. The session continued with gentle prompts that enabled them to describe their experiences, including: "Could you please share with us your stories and lived experiences about becoming a mother?

- Can you explain the challenges that you experienced during pregnancy?

- How about the strategies and the support that help you cope with these challenges to continue with the pregnancy?

The researcher used an open-ended question to allow the participants to talk about their experiences. The participants were encouraged to elaborate if their accounts were brief and not well understood by the researchers. For example, "Just now you were saying that...could you please elaborate more. The interviews were audiotaped, transcribed verbatim, and later given to the participants for verification.

Analysis began by ensuring all identifying details were disguised in or deleted from transcripts, and pseudonyms were applied. The researcher used the endeavor to understand how women made sense of their experience, regular discussions, reflections, and applied. The researcher used the Interpretative Phenomenological Analysis (Smith et al. 2004), and Qualitative Data Analysis (QDA) was used to assist in the analysis. This study received approval from the Medical and Research Ethics Committee of Universiti Teknologi MARA, Malaysia; 600-IRMI (5/1/6); REC/502/18 and the related Islamic Religious Council.

\subsection{Findings}

A total of 10 young women age between 19 to 23 years old, who had experienced pregnancy during adolescence, were interviewed. Most of them failed to finish their studies at secondary school, and all of them had experienced unwanted and wedlock pregnancy. Two of them plan to marry their partners after their release. Most of them stay with their mother. However, a respondent lived with her grandmother as her parents divorced. Four themes emerged from the analyses: i) trajectory of sexual activity, ii) the struggle of motherhood for un-wed teenage mothers, iii) the formula of resilience adolescent mothers, and iv) life after the misery.

\subsection{Theme 1: Trajectory of Sexual Activity}

Most of them said that it was only a matter of time after their meeting before they had sexual intercourse. One of the participants further described, "When I started working, I rarely went back home. Every time I went out with my boyfriend, we went clubbing, and this close relationship made it happen." (Miss S, 22).

This study revealed that indirect relationships (communication via telephone and the internet) were found as the main trajectory to initiate sexual activity among most of the respondents. They agreed that this influence more and increased their desire for sexual activity as fast as at their first meeting. "I know my boyfriend from "WeChat" after sometimes he persuades to meet. We were so close and intimate during this first dating. After a while, he started to touch me that trigger the sexual activity" (Miss T, 18).

They also described themselves as "social person,"; the term used for those who sought freedom with un-control behavior; seeking for something new and risky which normally related with a personal characteristic from a problematic and broken family, peer and partner influence, and social media. A respondent explained, "I started to fall in love since secondary school. After that, I became a "social person" I did not go back home. I followed what my friends did until I saw them having sexual intercourse (SI) in front of me. I asked my friend what they were doing, but she said nothing. Since I became friends with them, I started to follow their bad activity" (Miss N, 19) 
Un-harmonized family relationships and lack of inappropriate religious control were found to be the causes of the trajectory of sexual activity among the youngster as revealed by Miss $S$ who pregnant at the age of 19 years old; "My parent often fight, and these lessen my respect to them. My father was a very strict person, and my mother nags most of the time. I felt bored and will spend most of my time in school until I met with this Chinese guy that was nice and caring. The love and affection that she gains from him soon initiate the SI.

Almost all the respondents initiated their SI voluntarily and shared the difficulties of controlling the obsession or addiction of having sexual activities with their partner. Some of them repeated the SI due to love and infatuation; "It's because of love I was willing to have sex with him" (Miss N, 19); "After having SI at the first time, I felt obsessed and will repeat every time my partner approached me until eventually I was addicted and would ask for more and started to find a new partner fulfill this desire (Miss T, 18-year-old who initiated SI during the age of 16 years old)

There was a case where the SI happened without the respondent's conscious, but her altercation exposed her to sexual activity. "On that day, I went out for a motorcycle convoy with the guy that I just met through social media and his friends. That night, I was placed with the guy in a room, and I experienced my first un-expected SI. After a week, I started looking for the guy again as I was afraid of losing him because he was the first man, I had SI with; and this was how the SI repeated. (Miss Su, 19).

Most of the respondents claimed that they did not get proper sexual education, especially family planning, which lead to this unwanted pregnancy. "I gain inappropriate information about sex from my parent during my early secondary age. But I learned it more through my friends who experienced it. I am not really sure about family planning, although I had learned during my school time, and I didn't understand it well" (Miss R, 23).

\subsection{Theme 2: Struggles of Motherhood to Un-Wed Teenage Mother}

Most participants had a similar feeling of startled, worried, unexpected, fear, and worry regarding their pregnancy; they never expected it at an earlier age. "I was shocked when my pregnancy test showed double line after my menses delayed." (Miss F, 19).

Initially, they had the intention to terminate their pregnancy as the pregnancy was out of wedlock. However, the thought of family's and partners' reactions initiate the thought of sharing their pregnancy with them. "When I knew I was pregnant, I thought of terminating it, but I was so scared, thinking of my family's acceptance." (Miss N, 19).

The acceptance and the support from family, friend, and partner gave them the strength to continue the pregnancy. "My mother had discussed with my father, and they decided to keep the baby. They also will find ways to keep the baby from other people's knowledge." (Miss KL, 20).

Besides, the maternal feelings arose, and they felt a deep emotional bond with their baby as they first experienced the fetal movement. "I can feel the baby kicking in my tummy. Although I am not married to the father, I love my baby. I feel that I was responsible for my baby." (Miss SS, 19).

\subsection{Theme 3: The Role of Shelter Homes in Unwed Teenage Pregnancy}

In the beginning, due to shame of being pregnant out of wedlock, sense of responsibility in continuing the pregnancy, most respondents had no other option except to be placed in a shelter home. Their strength mainly stemmed from their child and the support from family. One of the participants described, "After he sent me to the clinic, that day I know I was pregnant, without waiting for some time, I immediately came here because I didn't know where to go. At that moment, I thought about my child, and I did not want my child to get the illegal source from what I had done. I will not allow my child to live the way I live now. So, I did not think much. I just called Miss Zara. Soon they reached Terengganu and brought me here" (Miss SS, 19).

Although being in the shelter home is not their preference, they had to adapt and face some challenges. Still, the majority of the respondents agreed that the shelter home not only able to provide a supportive place for pregnant and parenting teens, but it also allowed opportunities to improve themselves by strengthen their religious knowledge and practices and prepare themselves to begin with a new life. "Maybe others claimed that living in a shelter home is like a prison, but for me, it is not because we were allowed to have our activities here. We learned to recite AI-Quran, pray which I had never practiced before. But after being here, I can recite Al-Quran completely" (Miss KL, 20). "I felt more peaceful when I am at this place in which I can perform good religious practices I've never done before," (Miss F, 19, who had been in this shelter home for more than six months and had adjusted with the life in shelter home).

\subsection{Theme 4: Life after the Misery}

After all the pregnancy hardships, most of them intend to work and wish to be a good mother for their baby. They prefer their child to have a better religious practice to prevent and control premarital sex in the future. "Because I think I can manage to support my baby by working (Miss S, 22). One of the respondents mentioned, "I will have my baby back to stay with me, and I will make sure that he has better religious practices, and I wish to be a good example for my children so that they won't end up like me. I will work to support my children" (Miss R, 23).

The teenage mothers did not regret their decision to continue with the pregnancy. Most of the participants mentioned that they intend to work, and with good support, they wish to be a good mother for their baby. These plans occurred based on the experiences of teenage mothers. They plan to improve anything that can lead their child to expose to risky behavior. In other words, the teenage mothers wanted to care for their children in a way that they had not experienced (Seamark \& Lings, 2004). 


\subsection{Discussion.}

The objective of this study is to understand the meaning of lived experiences of having unintended teenage pregnancy and the strategies addressing this phenomenon, which emerge with four themes: i) trajectory of sexual activity, ii) the struggle of motherhood for un-wed teenage mother, iii) the formula of resilience teenage mothers, and iv) life after the misery.

Many factors contribute to the initiation of sexual activity among the youngster, such as being in an intimate relationship, personal characteristics, influences from others, and inadequate information about sexual health. Sexual activity might happen through a close, intimate, and romantic relationship. Most of the respondents said that before initiating the sexual activity, they had such a direct, intimate, close, and passionate relationship with their partner that starts to trigger their feelings for one another. The romantic relationship is the main factor influencing the teenager to have sex before marriage, which could lead to pregnancy out of wedlock (Abd Ghadur \& Abdul Kadir, 2009).

However, this study also found that indirect relationships, such as through social media, triggered sexual activity to happen faster as fast as their first meeting. Wolak and colleagues (2008) confirmed that while those who interact only with those, they know offline experience aggressive sexual solicitations at a very low rate (1 percent), those who interact freely with others online are at differential risk for solicitation on the specifics of their online interactions. Exchanging personal information and photos, talking about sex, and harassing others are associated with much higher online sexual solicitation rates. Similar findings have been reported by Collins et al. (2019).

Other than that, the personal character and influences aggravating teenage pregnancy incidence as Jas Laile Suzana (2005) mentioned that adolescents are motivated to involve with sex before marriage mainly because of influence and peer support besides a poor understanding of religiosity and moral values.

Besides, teenagers from broken families had a higher ratio of having a sexual activity to express their dissatisfaction with their families. The previous study said that teenagers from divorced parents were nearly two times more exposed to teenage pregnancy than those from married parents (Habitu et al., 2018). They start to spend much time with their friends rather than family, bad behavior as influenced by friends. They also start to find somebody that responds to them, starts to have a boyfriend, and initiate the feelings towards one another. A few of them start to familiarize themselves with drugs as their partner is a drug dealer. The previous study had mentioned that a good relationship between youth and their family members provide stable emotional support and are less likely to be associated with delinquent peers or tendency towards inappropriate behavior. (Brezina \& Azimi, 2018).

The reasons for pregnancy out of wedlock among teenagers vary; it could occur voluntarily or involuntarily. (Saim, 2013). People that had sex voluntarily usually state that they have the feeling of love towards one another. As stated from the previous finding. One of the reasons girls involved in sex with their boyfriends was to prove their love while the boys claimed they are just having fun (Abdullah et al., 2014).

Most of the respondents said they had never learned proper sexual education, and they only heard it from their friends. Even though some of them had learned it during their lower secondary school, understanding this topic remains unclear. This deviates the statement regarding School-based sexuality education (SBSE), which existed for almost a century (Moran, 2000), represents a formalized attempt to prevent such negative outcomes through the provision of information and the cultivation of sexual knowledge and values. (Bay-cheng, 2010). This statement from the United States contradicts the effect of sexual education in Malaysia, as the different acceptance and method of subject delivered regarding sexual education. Besides, 9 out of 10 respondents had claimed that they did not know about family planning. The remained one respondent had mentioned that she had used the family planning method but still pregnant. Thus, concluding the approach of sexual information is still inadequate.

A study of "experiences of pregnancy and motherhood among teenage mothers in a suburb of Accra" had explored adolescent mothers' experiences during pregnancy, childbirth, and care of their newborns. Their study's findings were that majority of the participants did not know they were pregnant (N.Y. \& A., 2013). It has been noted that the teenagers did not expect to have the pregnancy at an early age. They experience emotional disturbance that leads to irrational thoughts and decisions. As a result, the teenagers dared to decide to terminate their pregnancy. They blamed themselves, as they did not abstain enough to engage in a sexual relationship until she was ready to be a mother (James et al., 2012).

In continuation of the pregnancy, the teenage mothers receive encouragement from the religious aspect, the baby itself, and the family's acceptance toward the pregnancy. The transformation of self and transition to motherhood as a positive experience ultimately made life-changing decisions (keeping the baby) and understood their decisions' responsibility and weight (Azmawaty et al., 2019).

Besides, the decision to continue pregnancy because of the baby was supported by the previous study that mentioned the teenage mothers had very positive attitudes to being a mother and had felt an immediate bonding relationship when the baby was born (Seamark \& Lings, 2004).

The acceptance and support from family help in overcoming the challenges during pregnancy. The level of support received by teenage mothers substantially influenced their intentions and capacity to re-engage with their future (Ngum Chi Watts et al., 2015). The more support received from the family, the more likely they to carry on as they wish to become a better person in the future.

In the aspect of religion, it is supported by a study done by Ghani et al., (2014); they believed that religiosity of the individual should be supported with other elements, such as spiritual and moral values, to decrease individuals' involvement in premarital sex.

Although the acceptance of shelter homes as part of the strategies in handling teenage pregnancy in Malaysia is still the best strategy to deal with pregnancy out of wedlock other than marriage and abortion (Rains, 2009). According to the Malaysian Child Act (2006), unwed teenage mothers are considered to be exposed to sexual abuse and urgently need protection. The shelter homes should 
accordingly serve as residential correctional facilities to prevent pregnancy recidivism out of wedlock by giving protection, supervision, rehabilitation, and training (Care Centre Act, 2006; Dar Assaadah, 2008).

This study found that the shelter house is an institution that provides protection, rehabilitation, and training to its residents. Most of the respondents describe that the shelter home is the best place to prepare themselves with skills, knowledge, and practice after leaving the shelter home. In contrast with the previous study regarding the social support, resilience, and mental health in Malaysian for unwed young pregnant women and young mothers, their stay in the shelter home did not appear to significantly influence their coping skills, resilience, or social support (Saim, 2013). The difference might be due to their period of staying at the shelter home. As in our study, most of our respondents had been attached to the shelter home for more than six months. Thus, this influences the way in view and adapting to the environment.

\subsection{Conclusion \& Recommendation}

The teenage mothers experienced numerous challenges to cope with the un-wed pregnancy. The start of teenage pregnancy is due to early engagement with sexual activity. The trajectory to the sexual activity in such an indirect relationship (communication via telephone and the internet) increases sexual activity desire. Besides, having a broken family, peer pressure, and lack of knowledge of sexuality and reproductive health were the main contributing factors. Moreover, they shared difficulties in controlling their obsession or addiction to have sexual activities. At first, the teenagers were overwhelmed with ambivalent feelings of wanting to terminate the pregnancy, abandon the newborn, or to endure the journey of motherhood together with their ex-nuptial baby.

With good support from the family and shelter home, the teenagers managed to endure the challenges during an unwanted pregnancy. Despite that, it creates the formula of resiliencies towards un-wed pregnancy. They wish to raise their baby with the best education and practice to prevent and control premarital sex in the future.

Some recommendations are made for future research because the shelter home provided a supportive place for pregnant and parenting teens and allowed opportunities to strengthen their knowledge and practices such as religion in preparing themselves to start with a new life. In contrast with the previous study regarding the social support, resilience, and mental health in Malaysian for unwed young pregnant women and young mothers, their stay in the shelter home did not appear to significantly influence their coping skills, resilience, or social support. Hence, the government needs to standardize the approaches used for teenagers in a shelter home in Malaysia.

In this study, focused on the lived experiences of un-wed pregnancy from teenage mothers at the shelter home. Therefore, it is recommended involving the teenage mother who experiences un-wed pregnancy out of the shelter home is needed in the future.

\section{Acknowledgement}

We would like to acknowledge all the mothers participated in the study and the staff of the Jabatan Agama Islam Wilayah Persekutuan and Selangor, Malaysia. This study is partially sponsored partly by Universiti Teknologi MARA Grant, 600-IRMI/DANA KCM 5/3 LESTARI (108/2017) and 600-IRMI/DANA 5/3/BESTARI (P) (007/2018).

\section{References}

Abd Ghadur, S., \& Abdul Kadir, N. B. (2009). Hubungan romantik dan remaja hamil luar nikah di pusat pemulihan [Romantic relationship among unwed teenage mothers in a rehabilitation centre]. Journal e-Bangi, 4(1), 106-113.

Abdullah, S., Ghani, S. A., Sipon, S., \& Akil, S. M. S. (2014). Relationship between Parent and Peer Attachment with Coping Strategy among Teenagers Pregnancy. Procedia - Social and Behavioral Sciences, 114, 439-445. https://doi.org/10.1016/j.sbspro.2013.12.726

Azmawathy MNor, Shanina SAS, Usharani B, Zaida NZ (2019), The Turning Point in an Unwanted Teenage Pregnancy: A Psycho-emotional Perspective. Malaysian Journal of Medicine and Health Sciences (eISSN 2636-9346).

Dar Assaadah. (2008). Laporan tahunan 2008 [Annual report 2008]. Kuala Lumpur: Dar Assaadah.

Azri, M., Suan, M., Ismail, A. H., Medicine, M. F., \& Ghazali, H. (2015). ORIGINAL ARTICLE A review of teenage pregnancy research in Malaysia. Medical Journal Malaysia, 70(4), 214-219.

Bay-cheng, L. Y. (2010). Sex Education : Sexuality , Society and Learning The Trouble of Teen Sex : The construction of adolescent sexuality through school-based sexuality education, 1811. https://doi.org/10.1080/1468181032000052162

Behavior, S., Statistics, A., \& Alert, E. (2019). Start Download, (4), 1-8. https://doi.org/10.4103/0971-9962.218602

Case A. P., Hoyt A. T., Canfield M. A., Wilkinson A. V. (2015). Periconceptional risk factors for birth defects among younger and older teen mothers. Journal of Pediatric \& Adolescent Gynecology, 28, 263-270. doi: 10.1016/j.jpag.2014.09.004 [PubMed] [CrossRef] [Google Scholar] 
Collins, B. R. L., Martino, S. C., \& Shawrand, R. (2019). Influence Of New Media On Adolescent Sexual Health : Evidence And Influence Of New Media On Adolescent Sexual Health : Evidence And Opportunities, 1-46.

Jas Laile Suzana Jaafar. (2005). Takat keagamaan (religiosity) dan motivasi sosial seks sebelum nikah di kalangan remaja Melayu. Dlm. Roziah Omar dan Sivamurugum. (editor.). Malaysia isus-isu Sosial Semasa, pg. 27-40 Kuala Kumpur: Institut Sosial Malaysia. (in Malay).

Ganchimeg T, E Ota, N Morisaki, M Laopaiboon, P Lumbiganon, J Zhang, B Yamdamsuren, M Temmerman, L Say, Ö Tunçalp, JP Vogel, JP Souza, R Mori. Pregnancy and childbirth outcomes among adolescent mothers: A World Health Organization multicountry study. Internation Jounal of Obstetrics and Gynaecology. https://doi.org/10.1111/1471-0528.12630

Ghani, S. A., Abdullah, S., Akil, S. M. S., \& Nordin, N. (2014). Muslim Adolescent Moral Values and Coping Strategies among Muslim Female Adolescents Involved in Premarital Sex. Procedia - Social and Behavioral Sciences, 114, 637-643. https://doi.org/10.1016/j.jcp.2013.07.036

Habitu, Y. A., Yalew, A., \& Bisetegn, T. A. (2018). Prevalence and Factors Associated with Teenage Pregnancy , Northeast Ethiopia , 2017 : A Cross-Sectional Study, 2018. https://doi.org/10.1155/2018/1714527

James, S., Van Rooyen, D., \& Strümpher, J. (2012). Experiences of teenage pregnancy among Xhosa families. Midwifery, 28(2), $190-197$. https://doi.org/10.1016/..midw.2011.04.003

Khairani O, Suriati H, Azimah MN, et al. Adolescent pregnancy outcomes and risk factors in Malaysia. Int J Gynaecol Obstet 2010; 111(3): 220-3

Kawakita, T., Wilson, K., Grantz, K. L., Landy, H. J., Huang, C. C., \& Gomez-Lobo, V. (2016). Adverse Maternal and Neonatal Outcomes in Adolescent Pregnancy. Journal of Pediatric and Adolescent Gynecology, 29(2), 130-136. https://doi.org/10.1016/j.jpag.2015.08.006.

N.Y., K. G., \& A., A. (2013). Experiences of pregnancy and motherhood among teenage mothers in a suburb of Accra, Ghana: A qualitative study. International Journal of Women's Health, 5(1), 773-780. https://doi.org/10.2147/IJWH.S51528

Ngum Chi Watts, M. C., Liamputtong, P., \& McMichael, C. (2015). Early motherhood: A qualitative study exploring the experiences of African Australian teenage mothers in greater Melbourne, Australia. BMC Public Health, 15(1). https://doi.org/10.1186/s12889-015-2215-2

Rains, P. M. (2009). Becoming an unwed mother: A sociological account. Chicago: Aldine-Atherton.

Saim, N. J. (2013). Social support, coping, resilience and mental health in Malaysian unwed young pregnant women and young mothers Their experiences while living in a shelter home Nor Jana Saim. https://info.diva-portal.org/about-dival

Seamark, C. J., \& Lings, P. (2004). Positive experiences of teenage motherhood: A qualitative study. British Journal of General Practice, 54(508), 813-818. https://doi.org/jcs.01733 [pii]lr10.1242/jcs.01733

Sedgh, G., Sc, D., Finer, L. B., Ph, D., Bankole, A., Ph, D., ... Ph, D. (2015). Adolescent Pregnancy , Birth , and Abortion Rates Across Countries : Levels and Recent Trends. Journal of Adolescent Health, 56(2), 223-230. https://doi.org/10.1016/j.jadohealth.2014.09.007

Timothy Brezina \&Andia M. Azimi. Social Support, Loyalty to Delinquent Peers, and Offending: An Elaboration and Test of the Differential Social Support Hypothesis. Deviant Behavior. Volume 39, 2018 - Issue 5. https://doi.org/10.1080/01639625.2017.1286190

UNESCO. Early and Unintended Pregnancy \& the Education Sector: Evidence Review and Recommendations. Paris: UNESCO; 2017. http://www.ungei.org/Evidence_Review_early_unintended_pregnancy_.pdf

UNFPA(a). (2015). Girlhood, Not Motherhood. United Nations Population Fund. Retrieved from www.unfpa.org

Wolak J, Finkelhor D, Mitchell K. Is talking online to unknown people always risky? Distinguishing online interaction styles in a national sample of youth Internet users. CyberPsychology \& Behavior. 2008;11(3):340-343.

Yohannes Ayanaw Habitu, Anteneh Yalew, and Telake Azale Bisetegn.Prevalence and Factors Associated with Teenage Pregnancy, Northeast, Ethiopia, 2017: A CrossSectional Study. Hindawi Journal of Pregnancy Volume 2018, Article ID 1714527, 7 pages https://doi.org/10.1155/2018/1714527 